\title{
MOOC and English ESP teaching mode
}

\author{
Zheng Weiwei ${ }^{1, a}$ \\ ${ }^{1}$ Jilin Business and Technology College, Changchun, 130507, China \\ azhengweiwei@126.com
}

Keywords: College English, teaching mode, MOOC, ESP

\begin{abstract}
MOOC education is the most effective way to promote the development of college English ESP teaching, therefore, under the influence of MOOC education concept, the college English ESP teaching is continuously reforming. Our countries' college ESP teaching has just been carried for a short time, it still exists many problems in the teaching mode, which not only influences the development of the college English ESP teaching, but also influences the improvement of students' vocational English skills that bring great influence for students' future employment. And as the new teaching idea, the advantage of MOOC in ESP teaching is far away from other teaching methods. The traditional ESP in the teaching of college English faces many problems such as unclear teaching goals, backward teaching methods, lack of teaching materials, weak teaching staff and so on.
\end{abstract}

\section{The booming of MOOC and ESP teaching}

The rapid development of Internet and the intelligent mobile terminals not only greatly influence the development of science and technology, economy, military, etc, and also unprecedented influence on education. Since 2011, a new type of network education mode MOOC (Massive Open Online Course) has began to rise. This kind of large-scale, Open Online courses has brought great changes to the Internet, and quickly caused the attention of scholars both at home and abroad. Countries have launched their own open online courses, including Coursera, edX and Udacity, known as the troika "MOOC" platforms in the world, and attracted more and more universities, including Tsinghai university, Beijing university, Fudan university and other domestic famous universities.

MOOC shored for Massive Open Online Courses, belongs to the large-scale network Open courses, is also a new type of online courses. MOOC is mainly derived from the video courses and network remote education, rise as early as in 2008, the United States on the MOOC storm, which has given rise to online courses. In 2013, MOOC formally entered into China, Tsinghai university and Beijing university joined the online education work, after then the Shanghai Jiao tong university, Tong Ji university and other colleges and universities also added to the lesson. In order to effectively meet the demand of the informationization development of education, MOOC has become the new education idea, "MOOC" breaks the traditional teaching form, reflects the irreplaceable characteristics and advantages of openness, students can use the Internet to learn in terms of time and space limitations. "MOOC" has the characteristic of linear, it can realize the whole process of teaching management relying on abundant curriculum resources, and complete the teaching content. MOOC involves in the natural sciences, humanities and social science, etc., the students are able to choose courses according to their own needs, which differs from the traditional teaching mode, and in turn provides systemic and integrity guarantees for MOOC. Considering the interactive in MOOC is relatively long, teachers can put forward a topic for MOOC in a period of time; it can realize the effective connection between teachers and students, to realize the effective interaction between teachers and students.

English for Specific Purposes ( ESP) is great linked with the Specific subject, Specific profession, and Specific purpose, which requires combining learner training target and special requirements for learners to courses in English teaching, such as, business English, business English, financial English and advertising English and so on. ESP teaching can clear learners are learners with a 
purpose, and then combined with a specific industry development needs to improve science in English and English ability. At the same time also need to consider the specialized English teaching content and the particularity, under a certain working environment to foster students' English communication ability, combined with the social needs to promote college English ESP teaching, improve the ESP teaching effectiveness

MOOC has very big differences compared with the previous online education. First of all, MOOC is an open, free online education resource, with no basic requirements for learners status, and supports large populations participation, interactive teaching. Learners learn knowledge, share learning experience and learning process, realize the interaction between teachers and students, finish the homework, take tests in the MOOC platform, and they will also get the certificate after complete and systematic teaching process. MOOC, therefore, is more fit the general law of learning. At the same time, learners can hear world Class University courses form the forefront of multiple areas through MOOC platform at any time, make up the gap resulting from uneven distribution of education resources, to better achieve the democratic education.

\section{Challenges and enlightenment of MOOC}

MOOC is a kind of new teaching method, it teaches through the network platform which has the characteristics of wide scope of teaching pattern, large teaching scale, clear teaching concept, good teaching effect, it is also the most popular education concept in recent years. MOOC teaching content is mainly divided into two parts, the first is online education, mainly includes: micro small video class, class exercises, homework, discussion boards, and the final exam, etc.; the second is offline education, mainly includes: course BBS, FAQ section, after-school activities. In about 2008, MOOC education concept was proposed by Canada's famous scholars for the first time, since then MOOC education has been really researched and developed. It was not until 2011 that MOOC education was truly applied to math teaching, which was conducted by Sebas - tianThrun and Peter Norvig, both of them are at Stanford university, the famous researchers and developers of MOOC education, the course once the practice is supported by many scholars in colleges and universities and the affirmation, MOOC education the practice is known as one of the great reform in the history of education, is a milestone in the history of the development of education in the world. And in 2012, many international famous universities such as Harvard University, Oxford University, Yale university, university of Munich in Germany have set up a platform for class, for learners from different countries to provide the required knowledge of course content, thus highlight for class teaching has entered the development stage.

For primary challenge to the traditional foreign language teaching class, MOOC promotes the evolution of foreign language teaching resources to differentiation, and will stimulate the global teaching resources as the core of a new round of education competition. Weak teaching not only inherits all aspects of the constraints, but also faced the crisis of development and survival. Education cost and the quality of education is highly optimized for class key competitiveness. Because MOOC broke the course and receiving the limitation of time and space, a course registration may reach tens of thousands or even hundreds of thousands of students in class, a large number will make the offer for class and the learn lesson for both sides of the input costs are likely to infinite to shrink. At the same time, in addition to providing traditional standard curriculum for class, MOOC also provides a large number of innovative teaching to meet the requirements of the personalized needs, a move that easy to achieve education cost reduction and improve education quality, the virtuous circle of the highly unified and unparalleled unprecedented competition. Therefore, the traditional foreign language teaching reform has had no choice but to lose no time to use the current rapid development of network technology, in view of the different learners learning purpose, layer to provide more extensive and more exciting new forms of foreign language teaching and learning, can win the learners and seek development. In order to accurately grasp the direction of change, the development of foreign language education in colleges and universities need to clarify their first idea, accurate positioning is different from their lesson for the development of the field, and the reference for the teaching idea and advanced teaching methods at the same time, to 
discover, to fill a variety of development, according to different teaching goals, and longed for lesson on different teaching levels complement each other in parallel development.

\section{Main problems of college ESP teaching}

ESP teaching is the effective measure to improve students' English skills, and it can meet the learning needs of college students, so as to improve the students' professional ability. However, the ESP teaching just be carried out in our colleges and universities for a very short time, there are many problems in the teaching.

(1) The teaching goals are not clear. ESP teaching goal is to improve college students' overall English ability, make college students better adapt to his later work. However, most colleges and universities in China have focused on improving college students' English writing and reading ability, don't pay much attention to the training college students' English listening and speaking skills, which causes that a lot of college students gaining higher grades in English, but they are not capable to do a job related to English. For example, teachers working in the field of business English teaching in order to improve college students' English ability often use the whole language teaching, which is very useful to cultivate the ability of professional language sense. But teachers can't make professional English in the class, which causes students get high grades but lack professional English, making students are unable to take the job in reality. We can see that if English teachers can not make clear teaching targets, it will inevitably affect the students to improve professional ability of English.

(2) The teaching method is backward. Each college ESP teaching method is a common problem. With the development of education, colleges and universities has been constantly expanding, and colleges and universities teacher resources is inadequate, the teaching object and unequal between teachers for schools teaching has brought a lot of pressure, many colleges and universities in order to solve this problem, had to take open lectures a method of teaching, and in the face of so many students, English teachers can only take the way of translation teaching in the teaching, the teaching method is very backward, and the whole teaching process is the lack of interaction, the teacher fully occupy the main body status in teaching, as a result, students lose their interest in learning, students' learning effect is not ideal. We can see that this teaching mode can't meet the needs of the development of teaching not only, more difficult to meet the requirements of the teaching goal.

(3) The lack of teaching materials. Because university in our country carried out this teaching method for only a short time, the ESP teaching applied in teaching materials limited information, this brought serious influences in colleges and universities education, which is embodied in the following four aspects: firstly, materials used in ESP teaching are not only very scarce, and the teaching value is generally not high, which seriously influence the teaching quality. Secondly, the teaching content gives priority to with reading and writing knowledge, heard that knowledge is complementary, this completely contrary to the requirement of ESP teaching goad. Thirdly, the teaching material knowledge updates slowly, difficult to meet the needs of economic and social development. Frothy, after-school practice is still focused on filling in the blanks with vocabulary, sentence translation and so on, lacking exercises of practice content in the direction of professional ability making it difficult to improve the students' English practical ability.

(4) The teachers' ability is not strong. Most engaged in the work of the college ESP teaching teachers are graduated from English major, they generally English basic skill, oral English ability, but, at the university of ESP teaching is to improve the students' professional ability, although the teachers themselves have a strong professional background, but lack experience in teaching, practice ability is not strong, if let the university teachers according to the teaching material content for translation teaching is no problem, but if the teachers develop the students' ability of professional English is difficult to reach the effect of teaching, as a result, the teachers troop is not strong is an objective phenomenon, many colleges and universities generally have it brought serious impact to the ESP teaching, if teachers' teaching ability can not get a larger increase, then the ESP teaching is difficult to effectively. 


\section{Analysis of college ESP English teaching under the background of MOOC}

1) The use of MOOC to effective auxiliary college English ESP teaching, considering the "MOOC" rich teaching content, MOOC teaching activities have comprehensive, this will need to make full use of development advantages of MOOC learning evaluation and MOOC teaching feedback to make full use of the supporting role of MOOC in the actual teaching, to join in the college English curriculum system. Therefore, we need to combine with the actual development needs, respect for the university students' subjectivity and diversity from the angle of the MOOC and ESP teaching, and then make full use of the MOOC platform to provide effective supplement for ESP teaching combined with students' developing interest and professional background, changing the traditional teaching time and space constraints. Then it can improve learning aim, to internalize knowledge of college students, make full use of the MOOC to build college English ESP teaching mode, improve university English teaching effectiveness.

2) The construction of efficient network teaching resources platform on the basis of an analysis of the long-term perspective, ESP teaching process to build unity, sharing of teaching resources network platform. So-called teaching network platform, not just a school building alone, but many universities need to build cooperation relations, through the inter-school cooperation and school-based cooperation to build a high efficiency teaching resources platform, effectively break the barriers between universities and enterprises, so as to achieve effective teaching results of sharing and communication, the realization of ultimate learning resources sharing effectively. As a larger and long-term dynamic engineering, teaching resources construction work includes the corpus resources, material resources, and audio materials, and so on. For development under the background of" college English ESP teaching can make full use of modern information technology, make full use of network platform, rich resources of college English teaching, through the introduction of domestic and foreign teaching resources, through combining English teaching teachers and research staff, effective development of ESP teaching material, it can make students in the college English teachers to monitor and guide down effective development of teaching resources, to respect the principal position of students in the classroom, to cultivate students' autonomous learning education thought.

3) The construction of a diversified college English ESP teaching evaluation system in the process of "MOOC" teaching, mixed with a lot of interactive content and test content, so the system can automatically give feedback or evaluation. This can realize effective communication between teachers and students, between teachers and teachers and between students and students, promote mutual help between students, build effective evaluation activity. While building ESP evaluation activity at the same time, we also need to build a diversified evaluation system, making full use of the ESP network platform for the course to encouraged students to be able to communicate effectively with the teachers and students at the same time, teachers also need to be in combination with the practical situation of students to give more effective evaluation and effective feedback. In constructing college English ESP teaching mode, we need to adhere to the diversification of evaluation subject, adhere to the diversified evaluation through effective evaluation between teacher and student, student and student evaluation, each other between the students' self evaluation and etc. combined with the actual performance of students in the learning process and learning result, realizing the combination of summative assessment and formative assessment. But you still need to adhere to the function of formative assessment in one of the main body promoting college English teaching effectiveness evaluation.

\section{Summary}

Compared with the traditional linear education, MOOC is open with free education resources mostly, it can support more and more people involved in the teaching interaction. From the point of current college English education, the college English teaching is in the rigid development model because influence of the traditional education, which makes the students lack of interest in learning English and college English teaching effect is not very ideal. The rise of MOOC has a very large 
influence on our education system, education mode and education concept, education workers need to attaches great importance to the innovation of college English, make full use of the MOOC to improve their own quality, combining with the teaching method and teaching content to promote college English teaching reform. Use MOOC to lead the ESP teaching meeting the demand of college English teaching. College English teachers should make full use of the ESP developing mode to build the model of college English teaching mode, actively participate in the college English ESP teaching reform, continuously improve teachers' professional level, actively explore the ESP teaching mode, make full use of modern information technology to realize the sustainable development of college English ESP teaching.

\section{References}

[1] L.J.Niu. Explore of college English ESP teaching mode under the background MOOC [J]. Journal of course education research, 2016 (8) : 115-116.

[2] H.X.Xu. Study of the ESP teaching mode under the environment of MOOC [J]. Journal of contemporary research review, 2015 (2) : 6-6.

[3] S.H.Wang, K.L.Liu, W.P.Fu. Study of college English ESP teaching mode under the background of "MOOC"[J]. China audio-visual education, 2015 (4) : 97-101.

[4] L.Lian, F.Yuan, L.LWang. ESP theory and college oral English teaching based on the content [J]. Forest teaching, 2014 (9) : 44-45.

[5] B.Zhou. Research on how to use moving learning to improve higher vocational English teaching [J]. Journal of vocational technology, 2014 (10).

[6] M.J.Qian. New opportunities of the development of ESP in the mode of MOOC [J]. Overseas English, 2014 (7). 